\title{
Assessing healthcare providers' knowledge and practices relating to insecticide-treated nets and the prevention of malaria in Ghana, Laos, Senegal and Tanzania
}

\author{
Steven J Hoffman ${ }^{1,2,3,4}$, G Emmanuel Guindon ${ }^{5,6}$, John N Lavis ${ }^{1,2,6,7}$, Godwin D Ndossi ${ }^{8}$, Eric JA Osei ${ }^{9}$,
} Mintou Fall Sidibe ${ }^{10}$ and Boungnong Boupha ${ }^{1{ }^{*}}$, for the Research to Policy \& Practice Study Team

\begin{abstract}
Background: Research evidence is not always being disseminated to healthcare providers who need it to inform their clinical practice. This can result in the provision of ineffective services and an inefficient use of resources, the implications of which might be felt particularly acutely in low- and middle-income countries. Malaria prevention is a particularly compelling domain to study evidence/practice gaps given the proven efficacy, cost-effectiveness and disappointing utilization of insecticide-treated nets (ITNs).

Methods: This study compares what is known about ITNs to the related knowledge and practices of healthcare providers in four low- and middle-income countries. A new questionnaire was developed, pilot tested, translated and administered to 497 healthcare providers in Ghana (140), Laos (136), Senegal (100) and Tanzania (121). Ten questions tested participants' knowledge and clinical practice related to malaria prevention. Additional questions addressed their individual characteristics, working context and research-related activities. Ordinal logistic regressions with knowledge and practices as the dependent variable were conducted in addition to descriptive statistics.

Results: The survey achieved a 75\% response rate (372/497) across Ghana (107/140), Laos (136/136), Senegal (51/ 100) and Tanzania (78/121). Few participating healthcare providers correctly answered all five knowledge questions about ITNs (13\%) or self-reported performing all five clinical practices according to established evidence (2\%). Statistically significant factors associated with higher knowledge within each country included: 1) training in acquiring systematic reviews through the Cochrane Library (OR 2.48, 95\% Cl 1.30-4.73); and 2) ability to read and write English well or very well (OR 1.69, 95\% Cl 1.05-2.70). Statistically significant factors associated with better clinical practices within each country include: 1$)$ reading scientific journals from their own country $(\mathrm{OR} 1.67,95 \% \mathrm{Cl}$ 1.10-2.54); 2) working with researchers to improve their clinical practice or quality of working life (OR $1.44,95 \% \mathrm{Cl}$ 1.04-1.98); 3) training on malaria prevention since their last degree (OR 1.68, 95\% Cl 1.17-2.39); and 4) easy access to the internet (OR $1.52,95 \% \mathrm{Cl} 1.08-2.14)$.
\end{abstract}

Conclusions: Improving healthcare providers' knowledge and practices is an untapped opportunity for expanding ITN utilization and preventing malaria. This study points to several strategies that may help bridge the gap between what is known from research evidence and the knowledge and practices of healthcare providers. Training on acquiring systematic reviews and facilitating internet access may be particularly helpful.

\footnotetext{
* Correspondence: boungnong.boupha@gmail.com

${ }^{11}$ National Institute of Public Health, Ministry of Health, Vientiane, Lao

People's Democratic Republic

Full list of author information is available at the end of the article
} 


\section{Background}

There is growing awareness and concern among educators, researchers, practitioners and policymakers that what is known from research evidence is often not being put into action $[1,2]$. An expanding number of studies continue to show that research evidence is not being disseminated to healthcare providers who need it to inform their clinical practice and improve the health of their patients. Not only does this knowledge deficit lead to sub-optimal care, but it can result in the provision of ineffective services, inefficient use of resources and increasing inequities in health outcomes. This reality is particularly devastating for low-and middleincome countries which suffer from greater resource limitations than more affluent high-income countries. This situation is particularly salient when there are several cost-effective interventions that exist to prevent and address some of today's greatest global health challenges [3]. They are just not all being appropriately utilized.

Efforts to address malaria are particularly implicated by this "know-do" gap given the proven effectiveness of insecticide-treated nets (ITNs) in preventing the disease [4-6], this intervention's cost-effectiveness [7-10], and disappointing patterns in their utilization. The World Malaria Report 2009 highlights that only 31\% of African households own at least one ITN and that only $24 \%$ of children ( $<5$ years) used an ITN for at least one day in 2008 [11]. These statistics are well below the World Health Assembly's target of $80 \%$ coverage [12]. Research shows that intensive malaria control, and particularly preventative ITNs, can help countries meet the Millennium Development Goals of reducing child mortality by two-thirds (Goal 4) and reversing malaria's incidence worldwide (Goal 6) [3,12-14]. The full implementation of existing malaria interventions like ITNs is also expected to contribute to eradicating extreme poverty and hunger (Goal 1), achieving universal primary education (Goal 2), improving maternal health (Goal 5), and developing a global partnership for development (Goal $8)$, which includes access to affordable drugs $[7,15]$. Immediate action is clearly necessary.

This study seeks to probe the gap between what is known globally through research evidence about malaria prevention interventions (specifically ITNs) and the related knowledge and practices of healthcare providers in low- and middle-income countries. While many studies have asked community members about their knowledge and practices relating to malaria prevention [16-39], none could be found that asked these same questions of healthcare providers-who are intuitively and empirically known to influence their patients' behaviour in a variety of contexts [40-44]. In contrast, many studies of healthcare providers' knowledge and practices have addressed malaria diagnosis, treatment, management and transmission [45-50], and the prevention of other conditions, including cancer [51-60], dehydration from diarrhea [61-68] and pregnancy [69-73]. A better understanding of the factors that influence whether healthcare providers in low- and middleincome countries are knowledgeable about and optimally practice malaria prevention will serve to inform efforts aiming to eliminate the global burden of this disease for the future.

\section{Methods}

This inquiry is part of a larger study sponsored by the World Health Organization that examined the link between research, practice and policy. Other elements of this global effort have focused on whether and how healthcare providers use research evidence [74,75] and the extent to which researchers support its use [76,77]. This is the first time that the collected data on healthcare providers' knowledge and practices has been analysed and presented.

\section{Questionnaire design}

The development, translation, pilot-testing, reliability and validity of the questionnaire administered in this study has been described elsewhere [74]. In summary, the instrument was based on nine existing questionnaires [78-86]. The survey instrument included items about the respondents' individual characteristics, working context, training, networking activities, and access to, trust in and use of research evidence. There were also five true/false questions testing respondents' knowledge of malaria prevention and five questions assessing relevant clinical practices that were developed from multiple sources [87-90]. The instrument was found to have high internal consistency (i.e., reliability) and content and face validity. It was translated into Lao and French for administration in Laos and Senegal [74].

\section{Data collection}

The questionnaire was administered locally between October 2004 and December 2005 by country teams in Ghana, Laos, Senegal and Tanzania with each aiming to obtain complete responses from 100 healthcare providers. These four low- and lower-middle-income countries differ in population size, per capita income, health expenditures, life expectancy, coverage for ITNs, and computer and internet access (Table 1).

In Ghana, the country team constructed a sampling frame of appropriate healthcare providers from lists of government and private health facilities obtained from the Ministry of Health and the Society of Private Medical \& Dental Practitioners respectively. A stratified cluster random sampling process was used with the facilities stratified by region (Greater Accra and Ashanti) and 
Table 1 Country Profiles in 2005

\begin{tabular}{|c|c|c|c|c|c|}
\hline Country & Ghana & Laos & Senegal & Tanzania & Source \\
\hline Population (in millions) & 22 & 6 & 12 & 38 & [91] \\
\hline GDP per capita (in PPP int'l \$) & 2,607 & 2,147 & 1,926 & 750 & [92] \\
\hline Per capita total expenditure on health (in PPP int'l \$) & 95 & 74 & 72 & 29 & [93] \\
\hline Per capita government expenditure on health (in PPP int'l \$) & 40 & 15 & 29 & 12 & [93] \\
\hline Life expectancy at birth for males/females (in years) & $58 / 59$ & $61 / 63$ & $60 / 64$ & $49 / 51$ & [94] \\
\hline Children under-five mortality rate (per 1, 000 live births) & 112 & 79 & 136 & 122 & [94] \\
\hline Children under five sleeping under a net $(\%, 2003-2006)$ & 33 & 82 & 14 & 31 & [95] \\
\hline Children under five sleeping under an ITN $(\%, 2003-2006)$ & 22 & 18 & 7 & 16 & [95] \\
\hline Personal computers per population $(\%, 2004)$ & 1 & 0 & 2 & 1 & [94] \\
\hline Internet users per population $(\%, 2004)$ & 2 & 0 & 5 & 1 & [94] \\
\hline
\end{tabular}

Data are for 2005 unless otherwise indicated

governance (public vs. private) and then selected randomly for inclusion. 140 healthcare providers were approached representing 48 different facilities. In Laos, a sampling frame was constructed based on existing lists of providers from the Ministry of Health and four provincial health departments. A stratified random sampling process was similarly applied to select 136 healthcare providers who worked at different types of facilities (central, provincial and district hospitals) in Borikhamsay, Savannakheth and Vientiane. In Senegal, a sampling frame was developed from lists of providers working at eight Dakar- or Thiès-based institutions and a list of clinician-scientists they had previously constructed. Simple random sampling was used to select 100 healthcare providers. Finally, in Tanzania, country investigators used purposive sampling to identify 121 regional or district medical officers who were attending a meeting for malaria and the integrated management of childhood illness. These variations in sampling frames and methodology, and the limited sample size, preclude meaningful between-country comparisons.

\section{Data analysis}

Basic descriptive statistics were calculated for relevant items. In addition, simple ordinal logistic models were used to explore factors associated with the healthcare providers' knowledge and practices relating to ITNs and malaria prevention. Composite knowledge scores were constructed for each respondent based on the proportion of the five true/false knowledge-testing questions that they answered correctly. All questions were weighted equally and no penalty was given for incorrect answers. Similarly, composite practice scores were constructed for each respondent based on the frequency in which they reported doing the five practices on a fivepoint scale (i.e., 1 "never", 2 "rarely", 3 "sometimes", 4 "often", and 5 "very often"). The scale was inverted for the one practice which is contrary to recommended practice. All questions were weighted equally such that individual practice scores were integers ranging from five to 25. Both knowledge and practice scores were transformed into quintiles (within each country) and used as ordinal variables. Independent variables for both models included healthcare providers' 1) use of particular sources of evidence, 2) views and activities related to improving clinical practice, and 3) individual and practice characteristics. Multiple imputation (using 100 imputations) was used to fill in missing values using multivariate normal regressions. This approach was selected because it accommodates arbitrary missingvalue patterns [96]. Observations were excluded when the dependent variable was missing. All statistical analyses were conducted using Stata/MP 11.2 for Macintosh.

In the analysis, systematic reviews (and the Cochrane Library as the single most comprehensive source) are emphasized because they are widely recognized as the best available approach to the synthesis of global research evidence, they efficiently provide summary information to inform decision-making, and they are widely-available and internationally authoritative on clinical interventions [97-99], including ITNs for the prevention of malaria [4-6]. Previous studies informed the decision to differentiate between scientific journals from high-income countries and the respondents' own country as well as between full reports and summaries $[75,80,100]$.

\section{Results}

372 healthcare providers participated in this study out of the 497 providers approached, yielding an overall response rate of $75 \%$ (107 of 140 from Ghana, 136 of 136 from Laos, 51 of 100 from Senegal, and 78 of 121 from Tanzania).

A majority of the respondents were male (56\%), trained as primary care physicians $(67 \%)$, could read and 
write English (63\%), and worked in rural areas (56\%), government-operated facilities (86\%) and hospitals (82\%). On average, the respondents were 42 years old and spent the greatest percentage of their time on clinical practice $(59 \%)$ rather than research $(8 \%)$, teaching $(10 \%)$ or administrative duties $(18 \%)$. Few had easy access to a computer with a CD ROM (24\%) or the internet (22\%), had earned master's or doctorate degrees $(15 \%)$, and worked with researchers $(44 \%)$. Few of the respondents had training on acquiring, assessing or adapting research evidence since their last degree although a substantial number received training related specifically to malaria prevention (45\%). There were also few respondents that self-reported using the electronic Cochrane Library at least once a month (11\%), but relatively more that self-reported reading electronic or paper versions of clinical practice guidelines, protocols or decision-support tools (59\%), scientific journals from either their own country (55\%) or high-income countries (36\%), and summaries of articles, reports and reviews from public or non-profit organizations (57\%). Almost half of the participating healthcare providers reported that research performed in their own country was of above average or excellent quality (48\%) (Table 2).

Few participating healthcare providers correctly answered all five knowledge questions about ITNs (13\%), whether from Ghana (10\%), Laos (0\%), Senegal (4\%) or Tanzania (33\%). The overall percentage of correct responses to individual questions ranged from $43 \%$ on the effectiveness of torn ITNs (question 1) to $68 \%$ on the protective effect of ITNs for non-users in the same house (question 2), with variation greatest within Senegal (8\%-98\%) and least within Tanzania (70\%-85\%). Approximately half of all participating healthcare providers knew that using untreated nets can divert extra biting to sleepers without nets in the same houses (48\%), that ITNs need regular re-treatment to remain effective while long-lasting ITNs do not (57\%), and that ITNs have been demonstrated to reduce the number of malaria episodes in communities with stable malaria (57\%) (Table 3).

Very few participating healthcare providers selfreported performing all five clinical practices according to established evidence (2\%), whether from Ghana (1\%), Laos (1\%), Senegal (4\%) or Tanzania (5\%). Approximately half of providers often or very often reported that they enquired about young children's home-use of ITNs (52\%), recommended to caregivers that young children use them (56\%) and advised caregivers on the need to regularly re-treat them (46\%). A quarter of the participating healthcare providers reported often or very often giving ITNs to the caretakers of young children and pregnant women $(26 \%)$. More than one-third of the respondents self-reported that they often or very often incorrectly informed caretakers that torn ITNs are worse than no ITNs (37\%) (Table 4).

The first ordinal logistic model revealed two statistically significant factors associated with healthcare providers having higher knowledge scores related to malaria prevention: 1) training in acquiring systematic reviews through the Cochrane Library since completing their last degree (odds ratio [OR] 2.82, 95\% confidence interval [CI] 1.08-7.36); and 2) the ability to read and write English well or very well (OR 1.92, 95\% CI 1.37-2.69). The second ordinal logistic model highlighted several factors associated with healthcare providers following better practices relating to malaria prevention, namely: 1) reading scientific journals from their own country (OR 1.67, 95\% CI 1.10-2.54); 2) working with researchers to improve their clinical practice or quality of working life (OR 1.44, 95\% CI 1.04-1.98); 3) training on malaria prevention since their last degree (OR 1.68, 95\% CI 1.17-2.39); and 4) easy access to the internet (OR 1.52, 95\% CI 1.08-2.14) (Table 5).

\section{Discussion}

\section{Principal findings}

There is room for improvement in the knowledge and practices relevant to the prevention of malaria among the healthcare providers in low- and middle-income countries that were included in this study. Many misconceptions of ITNs remain common even among highly educated healthcare providers. For example, many participating healthcare providers did not know that the use of untreated nets can divert extra biting to sleepers without nets in the same home, and many of them self-reported that they often (incorrectly) informed patients that torn ITNs are worse than no ITNs. These gaps in knowledge and practices on the prevention of malaria align with other gaps that have been well-documented among households on the same issue [16-39] and healthcare providers on the diagnosis, treatment and transmission of malaria in low- and middle-income countries [45-50] and other diseases and conditions around the world [51-73,101-122].

This study also found various alterable factors that were associated with higher knowledge and better practices. For example, healthcare providers that had access to the internet and training in malaria prevention reported better practices relating to malaria prevention than those who did not. This study also indicates that healthcare providers who read journals from their own country not only self-report that these journals lead to changes in their clinical practice, as previous studies have found $[75,80]$, but that reading these journals is actually associated with better self-reported practices. In addition, this study confirms the importance of interactions between healthcare providers and researchers for 
Table 2 Descriptive statistics on healthcare providers' individual characteristics, working context, and views about and use of research evidence

\begin{tabular}{|c|c|c|c|c|c|}
\hline Factor & $\begin{array}{l}\text { All } \\
N= \\
372\end{array}$ & $\begin{array}{l}\text { Ghana } \\
N= \\
107\end{array}$ & $\begin{array}{l}\text { Laos } \\
N= \\
136\end{array}$ & $\begin{array}{l}\text { Senegal } \\
\mathrm{N}=51\end{array}$ & $\begin{array}{l}\text { Tanzania } \\
\mathrm{N}=75\end{array}$ \\
\hline \multicolumn{6}{|l|}{ Individual characteristics } \\
\hline Age, yr, mean & 42.0 & 43.0 & 40.7 & 38.9 & 45.5 \\
\hline Sex, male & 55.9 & 59.8 & 41.2 & 45.1 & 84.9 \\
\hline \multicolumn{6}{|l|}{ Type of health care provider } \\
\hline General practitioner & $67.2 \%$ & $53.8 \%$ & $86.6 \%$ & $29.4 \%$ & $77.8 \%$ \\
\hline Specialist physician & $5.8 \%$ & $10.4 \%$ & $4.5 \%$ & $5.9 \%$ & $1.4 \%$ \\
\hline Nurse & $15.7 \%$ & $31.1 \%$ & $2.2 \%$ & $37.3 \%$ & $2.8 \%$ \\
\hline Health worker & $6.6 \%$ & $2.8 \%$ & $5.2 \%$ & $17.6 \%$ & $6.9 \%$ \\
\hline Other & $4.7 \%$ & $1.9 \%$ & $1.5 \%$ & $9.8 \%$ & $11.1 \%$ \\
\hline \multicolumn{6}{|l|}{ Allocation of time, \% of timet } \\
\hline Clinical practice & $59.0 \%$ & $71.0 \%$ & $65.0 \%$ & $63.6 \%$ & $28.4 \%$ \\
\hline Research & $7.7 \%$ & $7.6 \%$ & $6.4 \%$ & $15.8 \%$ & $4.8 \%$ \\
\hline Teaching & $10.3 \%$ & $10.2 \%$ & $9.5 \%$ & $6.6 \%$ & $14.4 \%$ \\
\hline Administration & $18.2 \%$ & $9.2 \%$ & $12.8 \%$ & $8.5 \%$ & $47.2 \%$ \\
\hline Master's or doctorate degree & $15.1 \%$ & $15.0 \%$ & $8.1 \%$ & $7.8 \%$ & $32.1 \%$ \\
\hline \multicolumn{6}{|l|}{ Training (since completed last degree) in: } \\
\hline Acquiring systematic reviews through the Cochrane Library & $8.3 \%$ & $12.1 \%$ & $4.4 \%$ & $4.1 \%$ & $19.4 \%$ \\
\hline Critically appraising systematic reviews & $10.8 \%$ & $16.8 \%$ & $3.7 \%$ & $6.3 \%$ & $33.3 \%$ \\
\hline Integrated Management of Childhood IIIness (IMCI) & $34.9 \%$ & $43.3 \%$ & $14.0 \%$ & $39.2 \%$ & $72.9 \%$ \\
\hline Prevention of malaria & $44.6 \%$ & $39.2 \%$ & $30.9 \%$ & $74.5 \%$ & $65.1 \%$ \\
\hline Easy access to personal computer with CD ROM & $24.3 \%$ & $22.6 \%$ & $7.5 \%$ & $31.4 \%$ & $56.3 \%$ \\
\hline Easy access to Internet & $21.7 \%$ & $21.8 \%$ & $6.7 \%$ & $43.1 \%$ & $35.9 \%$ \\
\hline Able to read and write English well or very well & $63.3 \%$ & $97.2 \%$ & $19.3 \%$ & $56.9 \%$ & $100 \%$ \\
\hline \multicolumn{6}{|l|}{ Working context§ } \\
\hline \multicolumn{6}{|l|}{ Operating authority of facility or practice } \\
\hline Government & $86.3 \%$ & $59.8 \%$ & $100 \%$ & $92.2 \%$ & $95.8 \%$ \\
\hline Nongovernmental organization & $14.5 \%$ & $26.2 \%$ & $4.4 \%$ & $7.8 \%$ & $21.1 \%$ \\
\hline For-profit organization & $9.6 \%$ & $23.4 \%$ & $0.7 \%$ & $0 \%$ & $12.7 \%$ \\
\hline \multicolumn{6}{|l|}{ Type of facility or practice } \\
\hline Solo or individual practice & $13.7 \%$ & $13.1 \%$ & $9.6 \%$ & $15.7 \%$ & $21.4 \%$ \\
\hline Group practice & $33.2 \%$ & $22.4 \%$ & $53.7 \%$ & $0 \%$ & $34.3 \%$ \\
\hline Hospital & $81.6 \%$ & $79.4 \%$ & $93.4 \%$ & $51.0 \%$ & $84.3 \%$ \\
\hline Community health centre & $25.0 \%$ & $20.6 \%$ & $0.7 \%$ & $56.9 \%$ & $55.7 \%$ \\
\hline \multicolumn{6}{|l|}{ Location of facility or practice } \\
\hline Urban & $16.0 \%$ & $4.7 \%$ & $2.4 \%$ & $31.4 \%$ & $44.6 \%$ \\
\hline Rural & $55.7 \%$ & $69.8 \%$ & $60.3 \%$ & $52.9 \%$ & $29.7 \%$ \\
\hline Mixed & $40.6 \%$ & $32.1 \%$ & $45.2 \%$ & $23.5 \%$ & $56.8 \%$ \\
\hline Facility had insecticide-treated nets (ITNs) available & $58.5 \%$ & $64.5 \%$ & $38.5 \%$ & $54.9 \%$ & $89.0 \%$ \\
\hline \multicolumn{6}{|l|}{ Views and activities related to improving clinical practice } \\
\hline Research performed in their own country is of above average or excellent quality & $47.8 \%$ & $57.3 \%$ & $28.2 \%$ & $39.2 \%$ & $75.3 \%$ \\
\hline Trust somewhat or completely a systematic review of randomized controlled double-blind trials & $55.5 \%$ & $58.7 \%$ & $48.1 \%$ & $47.1 \%$ & $72.6 \%$ \\
\hline $\begin{array}{l}\text { Working with researchers or research groups to improve clinical practice or the quality of } \\
\text { working life }\end{array}$ & $43.9 \%$ & $40.6 \%$ & $41.0 \%$ & $27.5 \%$ & $66.2 \%$ \\
\hline Higher quality of available research is important or very important to improve their work & $92.6 \%$ & $86.0 \%$ & $99.3 \%$ & $98.0 \%$ & $86.3 \%$ \\
\hline
\end{tabular}


Table 2 Descriptive statistics on healthcare providers?'? individual characteristics, working context, and views about and use of research evidence (Continued)

\begin{tabular}{|c|c|c|c|c|c|}
\hline \multicolumn{6}{|l|}{ Used or read particular sources of evidence } \\
\hline Clinical practice guidelines, protocols or decision-support tools & $59.4 \%$ & $65.7 \%$ & $47.7 \%$ & $51.0 \%$ & $80.0 \%$ \\
\hline Cochrane Library & $11.1 \%$ & $20.4 \%$ & $6.7 \%$ & $5.9 \%$ & $9.5 \%$ \\
\hline Scientific journals from high-income countries & $35.9 \%$ & $55.9 \%$ & $15.6 \%$ & $29.4 \%$ & $50.0 \%$ \\
\hline Scientific journals from own country & $55.1 \%$ & $53.6 \%$ & $64.9 \%$ & $17.6 \%$ & $67.2 \%$ \\
\hline Summaries of articles, reports, and reviews from public and not-for-profit health organizations & $56.9 \%$ & $64.1 \%$ & $36.4 \%$ & $78.4 \%$ & $69.2 \%$ \\
\hline
\end{tabular}

§May not add to $100 \%$ because health care providers may practise in more than one setting

tMay not add to $100 \%$ because the allocation of time reported by a small number of respondents did not add to $100 \%$

achieving evidence-based practice as has been widely reported in the research literature [123,124]. This study further offers some data and a baseline to help define the scope of this challenge.

The logistic models suggest that higher knowledge and better practices may be associated with different factors. While it may be the case that these factors influence knowledge and practices differently, these divergent results could also be explained by social desirability bias which presumably would affect self-reports of practices much more than it would affect answers to knowledgetesting questions. Alternatively, the models may lack sufficient power, the dependent variables may not adequately reflect respondents' real "knowledge" and "practice", or there may be confounding variables affecting the analysis.

\section{Policy implications}

Improving healthcare providers' knowledge and practices is an untapped opportunity for expanding ITN coverage and preventing malaria. Not only are healthcare providers the main source through which people learn about and use health interventions [1], but they are known to greatly influence their patients' healthrelated behaviours [40-44]. Now that gaps in knowledge and practices relating to malaria prevention have been identified, appropriate interventions targeting healthcare providers can be deployed with the possibility that small investments directed at this influential group may efficiently achieve significant returns across large populations. These interventions can be informed by the many studies conducted on how to bring about behaviour change among healthcare providers, including systematic reviews of studies on the effectiveness of audit and feedback [125], distribution of education materials [126], educational meetings [127], local opinion leaders [128], outreach visits [91], and reminders [129], as well as the Rx for Change and Health Systems Evidence databases which contain these types of reviews $[130,131]$. In addition, the results from this study also highlight several changeable factors that may be helpful for improving healthcare providers' knowledge and practices more broadly. This is information that national health policymakers, civil society leaders, donors and international organizations can use to design optimized strategies and evidence-informed policies that may lead to accelerated progress in this area.

Specifically, this study's results point to several possible areas in which interventions may be effective in helping healthcare providers attain greater knowledge on malaria prevention and evidence-based practices. First, the low proportion of healthcare providers who

Table 3 Questions assessing healthcare providers' knowledge of malaria prevention

\begin{tabular}{|c|c|c|c|c|c|}
\hline Question (True/False) & $\begin{array}{l}\text { All } \\
N=372\end{array}$ & $\begin{array}{l}\text { Ghana } \\
\mathrm{N}=107\end{array}$ & $\begin{array}{l}\text { Laos } \\
\mathrm{N}=136\end{array}$ & $\begin{array}{l}\text { Senegal } \\
N=51\end{array}$ & $\begin{array}{l}\text { Tanzania } \\
\mathrm{N}=75\end{array}$ \\
\hline Insecticide-treated nets that are torn are no longer effective and should not be used. [False] & $\begin{array}{l}43.3 \% \\
(158 / 365)\end{array}$ & $\begin{array}{l}32.4 \% \\
(34 / 105)\end{array}$ & $\begin{array}{l}50.7 \% \\
(69 / 136)\end{array}$ & $\begin{array}{l}7.8 \%(4 / \\
51)\end{array}$ & $\begin{array}{l}69.9 \% \\
(51 / 73)\end{array}$ \\
\hline $\begin{array}{l}\text { The use of insecticide-treated nets can reduce the number of bites in sleepers without nets } \\
\text { in the same houses. [True] }\end{array}$ & $\begin{array}{l}68.3 \% \\
(250 / 366)\end{array}$ & $\begin{array}{l}68.6 \% \\
(72 / 105)\end{array}$ & $\begin{array}{l}61.8 \% \\
(84 / 136)\end{array}$ & $\begin{array}{l}78.4 \% \\
(40 / 51)\end{array}$ & $\begin{array}{l}73.0 \% \\
(54 / 74)\end{array}$ \\
\hline $\begin{array}{l}\text { The use of untreated nets can divert extra biting to sleepers without nets in the same } \\
\text { houses. [True] }\end{array}$ & $\begin{array}{l}48.5 \% \\
(176 / 363)\end{array}$ & $\begin{array}{l}60.8 \% \\
(62 / 102)\end{array}$ & $\begin{array}{l}25.7 \% \\
(35 / 136)\end{array}$ & $\begin{array}{l}51.0 \% \\
(26 / 51)\end{array}$ & $\begin{array}{l}71.6 \% \\
(53 / 74)\end{array}$ \\
\hline $\begin{array}{l}\text { Insecticide-treated nets need regular re-treatment to remain effective while long-lasting } \\
\text { insecticidal nets remain effective for a long time and after many washes, without the need } \\
\text { for re-treatment. [True] }\end{array}$ & $\begin{array}{l}57.2 \% \\
(207 / 362)\end{array}$ & $\begin{array}{l}64.7 \% \\
(66 / 102)\end{array}$ & $\begin{array}{l}21.3 \% \\
(29 / 136)\end{array}$ & $\begin{array}{l}98.0 \% \\
(50 / 51)\end{array}$ & $\begin{array}{l}84.9 \% \\
(62 / 73)\end{array}$ \\
\hline $\begin{array}{l}\text { Insecticide-treated nets' ability to reduce the number of malaria episodes in communities } \\
\text { with stable malaria has not been demonstrated. [False] }\end{array}$ & $\begin{array}{l}56.6 \% \\
(206 / 364)\end{array}$ & $\begin{array}{l}69.5 \% \\
(73 / 105)\end{array}$ & $\begin{array}{l}19.9 \% \\
(27 / 136)\end{array}$ & $\begin{array}{l}88.2 \% \\
(45 / 51)\end{array}$ & $\begin{array}{l}84.7 \% \\
(61 / 72)\end{array}$ \\
\hline All answers correct & $4 \%$ & $10 \%$ & $0 \%$ & $4 \%$ & $33 \%$ \\
\hline
\end{tabular}

Data show the percentage and fraction of respondents who correctly answered each question 
Table 4 Questions assessing healthcare providers' practices relating to malaria prevention

\begin{tabular}{|c|c|c|c|c|c|}
\hline Question (Frequency) & $\begin{array}{l}\text { All } \\
\mathrm{N}=372\end{array}$ & $\begin{array}{l}\text { Ghana } \\
\mathrm{N}=107\end{array}$ & $\begin{array}{l}\text { Laos } \\
\mathrm{N}=136\end{array}$ & $\begin{array}{l}\text { Senegal } \\
\mathrm{N}=51\end{array}$ & $\begin{array}{l}\text { Tanzania } \\
\mathrm{N}=75\end{array}$ \\
\hline $\begin{array}{l}\text { When treating young children, how often did you enquire about their and their caretakers' } \\
\text { home-use of insecticide-treated nets? [Recommended practice] }\end{array}$ & $\begin{array}{l}51.9 \% \\
(191 / 368)\end{array}$ & $\begin{array}{l}57.9 \% \\
(62 / 107)\end{array}$ & $\begin{array}{l}41.9 \% \\
(57 / 136)\end{array}$ & $\begin{array}{l}33.3 \% \\
(17 / 51)\end{array}$ & $\begin{array}{l}74.3 \% \\
(55 / 74)\end{array}$ \\
\hline $\begin{array}{l}\text { When treating young children, how often did you recommend caretakers to use } \\
\text { insecticide-treated nets for their young children? [Recommended practice] }\end{array}$ & $\begin{array}{l}56.1 \% \\
(207 / 369)\end{array}$ & $\begin{array}{l}65.4 \% \\
(70 / 107)\end{array}$ & $\begin{array}{l}44.9 \% \\
(61 / 136)\end{array}$ & $\begin{array}{l}37.2 \% \\
(19 / 51)\end{array}$ & $\begin{array}{l}76.0 \% \\
(57 / 75)\end{array}$ \\
\hline $\begin{array}{l}\text { When treating young children, how often did you inform caretakers who used insecticide- } \\
\text { treated nets of the need to regularly re-treat their nets? [Recommended practice] }\end{array}$ & $\begin{array}{l}46.2 \% \\
(170 / 368)\end{array}$ & $\begin{array}{l}40.2 \% \\
(43 / 107)\end{array}$ & $\begin{array}{l}39.0 \% \\
(53 / 136)\end{array}$ & $\begin{array}{l}37.2 \% \\
(19 / 51)\end{array}$ & $\begin{array}{l}74.3 \% \\
(55 / 74)\end{array}$ \\
\hline $\begin{array}{l}\text { When treating young children and pregnant women, how often did you (or someone } \\
\text { acting on your behalf) provide caretakers and pregnant women with an insecticide-treated } \\
\text { nets for home-use? [Recommended practice] }\end{array}$ & $\begin{array}{l}26.3 \% \\
(97 / 368)\end{array}$ & $\begin{array}{l}31.1 \% \\
(33 / 106)\end{array}$ & $\begin{array}{l}15.4 \% \\
(21 / 136)\end{array}$ & $\begin{array}{l}33.3 \% \\
(17 / 51)\end{array}$ & $\begin{array}{l}34.7 \% \\
(26 / 75)\end{array}$ \\
\hline $\begin{array}{l}\text { When treating young children, how often did you inform caretakers that torn insecticide- } \\
\text { treated nets are worse than no insecticide-treated nets? [Contrary to recommended practice] }\end{array}$ & $\begin{array}{l}36.5 \% \\
(133 / 364)\end{array}$ & $\begin{array}{l}29.5 \% \\
(31 / 105)\end{array}$ & $\begin{array}{l}41.2 \% \\
(56 / 136)\end{array}$ & $\begin{array}{l}35.3 \% \\
(18 / 51)\end{array}$ & $\begin{array}{l}38.9 \% \\
(28 / 72)\end{array}$ \\
\hline All recommended practices & $2 \%$ & $1 \%$ & $1 \%$ & $4 \%$ & $5 \%$ \\
\hline
\end{tabular}

Data show the percentage and fraction of respondents who over the previous 12 months engaged in the recommended practices described in the first four questions either often or very often (vs. never, rarely, sometimes, and not applicable) and who never engaged in the non-recommended practice as described in the last question (vs. rarely, sometimes, often, very often, and not applicable)

received training in acquiring, assessing and adapting research evidence suggests such training is an opportunity for improvement-especially if it covers systematic reviews. Indeed, whereas graduate degrees and clinical specialization were not associated with greater knowledge on malaria prevention, training in acquiring systematic reviews through the Cochrane Library was. Second, improving access to computers and the internet may be fruitful. While only $11 \%$ of the total sample used the Cochrane Library (which is free in most low-income countries), this doubles to $25 \%$ for those who have easy access to the internet. Third, the fact that English language abilities were associated with higher knowledge suggests that the best health knowledge and/or training opportunities may not be available to healthcare providers in their local languages. Efforts to disseminate translated research syntheses may be helpful. Fourth, supporting interaction between healthcare providers and researchers may also be an effective strategy for improving clinical practice. Finally, access to scientific journals from healthcare providers' own country can be facilitated, especially as the studies they contain would be among the most applicable to their local context.

\section{Strengths and limitations of the study}

This study has five main strengths. First, it examines malaria, a disease prioritized in the Millennium Development Goals and which has a proven intervention for prevention that is not universally utilized (i.e., ITNs). Second, the study's questionnaire was built on existing questionnaires, pilot tested, and assessed for reliability and validity [74]. Third, data were collected from four low- and lower-middle-income countries with different life expectancies, coverage rates for ITNs, and other characteristics. Fourth, high response rates were achieved in three of four countries. Fifth, knowledge and practice scores were calculated from a range of testing questions for which the participating healthcare providers were not told the correct answer, which is a more objective metric than asking participants to self-evaluate whether they had "high" or "low" knowledge and practices as has been done in past studies.

This study has four main limitations. First, the survey relies on self-reported data to assess healthcare providers' practices which increases the risk of social desirability bias and may differ from actual performance. One review of studies conducted between 1980-1996 suggests self-reports of practices overestimate actual behaviour (in that case, of adherence to practice guidelines) by up to $27 \%$ [132]. Second, the composite knowledge and practice scores were based on responses to only ten questions. Third, linguistic and cultural differences may have affected respondents' interpretation of certain questions. Fourth, resource constraints prevented the survey of fully representative samples of healthcare providers in the four countries which means results cannot and should not be compared across countries. For example, participants in Tanzania were mostly district or regional medical officers who were attending a meeting on malaria-a group that would be expected to have relative good knowledge and practices-whereas the majority of respondents in Senegal were not physicians given this country's reliance on nurses and community health workers for preventative care. Future studies like this one, if possible, should be conducted using representative samples in order to enhance generalizability.

\section{Conclusions}

Increased attention is necessary to help bridge the gap between what is known from research evidence about preventing malaria and the knowledge and practices of healthcare providers in low- and middle-income 
Table 5 Ordinal logistic models for the factors associated with the log odds of having higher knowledge and better practices

\begin{tabular}{|c|c|c|c|c|}
\hline \multirow[t]{2}{*}{ Factor } & \multicolumn{2}{|c|}{$\begin{array}{l}\text { Knowledge } \\
(\mathrm{n}=340)\end{array}$} & \multicolumn{2}{|c|}{$\begin{array}{l}\text { Practices } \\
(\mathrm{n}=340)\end{array}$} \\
\hline & OR & $95 \% \mathrm{Cl}$ & OR & $95 \% \mathrm{Cl}$ \\
\hline \multicolumn{5}{|l|}{ Individual characteristics } \\
\hline$\overline{\text { Age }^{*}}$ & 1.07 & $(0.96,1.19)$ & 1.14 & $(0.94,1.38)$ \\
\hline Age squared* & 1.00 & $(1.00,1.00)$ & 1.00 & $(1.00,1.00)$ \\
\hline Sex, male & 1.16 & $(0.93,1.46)$ & 1.28 & $(0.98,1.68)$ \\
\hline Specialist physician & 1.15 & $(0.60,2.20)$ & 1.82 & $(0.71,4.65)$ \\
\hline Time allocated to research ** & 1.01 & $(1.00,1.01)$ & 1.01 & $(0.99,1.02)$ \\
\hline Master's or doctorate degree & 1.01 & $(0.81,1.26)$ & 0.81 & $(0.48,1.35)$ \\
\hline \multicolumn{5}{|l|}{ Training (since completed last degree) in: } \\
\hline Acquiring systematic reviews through the Cochrane Library & 2.82 & $(1.08,7.36)$ & 0.99 & $(0.49,2.00)$ \\
\hline Critically appraising systematic reviews & 0.77 & $(0.25,2.40)$ & 1.28 & $(0.66,2.47)$ \\
\hline Integrated Management of Childhood IIIness (IMCI) & 0.72 & $(0.41,1.28)$ & 0.95 & $(0.48,1.90)$ \\
\hline Prevention of malaria & 1.20 & $(0.73,1.97)$ & 1.68 & $(1.17,2.39)$ \\
\hline Easy access to a personal computer with a CD ROM & 1.50 & $(0.63,3.58)$ & 0.63 & $(0.28,1.43)$ \\
\hline Easy access to the internet & 1.07 & $(0.44,2.57)$ & 1.52 & $(1.08,2.14)$ \\
\hline Able to read and write English well or very well & 1.92 & $(1.37,2.69)$ & 1.00 & $(0.63,1.58)$ \\
\hline \multicolumn{5}{|l|}{ Working Context } \\
\hline Based in a facility or practice with an NGO as the operating authority & 0.90 & $(0.32,2.53)$ & 1.25 & $(0.66,2.37)$ \\
\hline Based in a hospital & 1.08 & $(0.83,1.39)$ & 0.66 & $(0.32,1.34)$ \\
\hline Located in an urban setting & 1.01 & $(0.85,1.19)$ & 1.00 & $(0.73,1.37)$ \\
\hline Facility had insecticide-treated nets (ITNs) available & 0.71 & $(0.35,1.46)$ & 2.58 & $(0.52,12.94)$ \\
\hline \multicolumn{5}{|l|}{ Views and activities related to improving clinical practice } \\
\hline Research performed in their own country is of above average or excellent quality & 0.78 & $(0.35,1.73)$ & 1.49 & $(0.88,2.53)$ \\
\hline Trust somewhat or completely a systematic review of randomized controlled double-blind trials & 1.06 & $(0.63,1.79)$ & 1.16 & $(0.52,2.58)$ \\
\hline Working with researchers or research groups to improve clinical practice or the quality of working life & 1.11 & $(0.69,1.78)$ & 1.44 & $(1.04,1.98)$ \\
\hline Higher quality of available research is important or very important to improve their work & 1.07 & $(0.54,2.14)$ & 0.63 & $(0.33,1.18)$ \\
\hline \multicolumn{5}{|l|}{ Used or read particular sources of evidence } \\
\hline Clinical practice guidelines, protocols or decision-support tools & 1.06 & $(0.71,1.60)$ & 1.32 & $(0.83,2.10)$ \\
\hline Cochrane Library & 0.68 & $(0.37,1.27)$ & 0.98 & $(0.56,1.70)$ \\
\hline Scientific journals from high-income countries & 1.09 & $(0.50,2.36)$ & 0.74 & $(0.47,1.16)$ \\
\hline Scientific journals from own country & 1.31 & $(0.88,1.95)$ & 1.67 & $(1.10,2.54)$ \\
\hline Summaries of articles, reports, and reviews from public and not-for-profit health organizations & 1.37 & $(0.50,3.75)$ & 1.27 & $(0.92,1.76)$ \\
\hline \multicolumn{5}{|l|}{ Thresholds } \\
\hline$\overline{k^{1}}$ & 1.81 & $(-0.29,3.91)$ & 2.59 & $(-2.31,7.49)$ \\
\hline $\mathrm{k}^{2}$ & 3.03 & $(1.23,4.84)$ & 3.87 & $(-0.99,8.73)$ \\
\hline$\overline{k^{3}}$ & 3.33 & $(1.16,5.49)$ & 4.99 & $(0.16,9.81)$ \\
\hline$k^{4}$ & 4.59 & $(1.90,7.28)$ & 5.92 & $(0.63,11.21)$ \\
\hline
\end{tabular}

$\mathrm{Cl}=$ confidence interval, $\mathrm{NGO}=$ nongovernmental organization, $\mathrm{OR}=$ odds ratio

Standard errors adjusted for 4 clusters (i.e., country). All regression models include country dummies (Tanzania is the reference country)

* Entered in regression models as continuous variables measured in years

** Entered in regression models as continuous variable measured in percent of time

countries. Until serious and multi-pronged efforts are implemented, we may never be able to fully capitalize on existing evidence-based and cost-effective interventions like ITNs for reducing the burden of malaria, addressing inequities and improving health globally. Those policymakers, civil society leaders, donors and international organizations who are working to prevent malaria should at least consider strategies to enhance 
healthcare provider' knowledge and evidence-based practice, such as offering training on acquiring systematic reviews, facilitating access to the internet, translating research syntheses to local languages, encouraging interactions with researchers, making ITNs available at healthcare facilities, and supporting the dissemination of local scientific journals. Further studies are necessary to both confirm these exploratory findings and more precisely inform future policy directions.

\section{Funding}

Funding for this project was provided by the Alliance for Health Policy \& Systems Research and the Global Development Network and supplemented with substantial in-kind support of staff time and other resources from McMaster University and the World Health Organization. John Lavis receives salary support as the Canada Research Chair in Knowledge Transfer and Exchange. The views expressed in this paper are those of the authors and do not represent the views of their affiliated organizations.

\section{Acknowledgements}

Members of the Research to Policy and Practice (RPP) Study Team include: John N. Lavis, G. Emmanuel Guindon, David Cameron and Steven J. Hoffman (Canada); Guang Shi and Tinglin Qiu (China); Eric J.A. Osei and Kudjoe Dovlo (Ghana); C.A.K. Yesudian and P. Ramachandran (India); Hossein Malek-Afzali, M. Dejman, K. Falahat, M. Baradaran, E. Habibi, H. Kohanzad, M. Nasehi and S. Salek (Iran); A.A. Akanov, B.S. Turdaliyeva, N.K. Hamzina, K.A. Tulebaev, T.I. Clazhneva, and G. Battakova (Kazakhstan); Boungnong Boupha, Sengchanh Kounnavong, and Latsamy Siengsounthone (Lao People's Democratic Republic); Francisco Becerra-Posada, Leticia Alfaro Ramos and Israel Mejia (Mexico); Tasleem Akhtar and M. Mubashir A. Khan (Pakistan); Mintou Fall Sidibe, Awa Sidibe, and Djiby Ndiaye (Senegal); Godwin D. Ndossi and Julius Massaga (Tanzania); and Ritu Sadana and Tikki Pang (World Health Organization)

We thank the technical experts who provided support to one or more phases of the study, the researchers who shared their questionnaires with us, and the participants in the project workshop that was held in Geneva to discuss the data-collection process, interim findings, and potential implications for dissemination and next steps. We also thank Andrew Kennedy and Carol D'Souza who provided scientific input in one or more phases of the study.

\section{Author details \\ 'McMaster Health Forum, McMaster University, Hamilton, Ontario, Canada. ${ }^{2}$ Department of Clinical Epidemiology and Biostatistics, McMaster University, Hamilton, Ontario, Canada. ${ }^{3}$ Global Health Diplomacy Program, Munk School of Global Affairs, University of Toronto, Toronto, Ontario, Canada. ${ }^{4}$ Interfaculty Initiative in Health Policy, Harvard University, Cambridge, MA, USA. ${ }^{5}$ Propel Centre for Population Health Impact, University of Waterloo, Waterloo, Ontario, Canada. ${ }^{6}$ Centre for Health Economics and Policy Analysis, McMaster University, Hamilton, Ontario, Canada. ${ }^{7}$ Department of Political Science, McMaster University, Hamilton, Ontario, Canada. ${ }^{8}$ Tanzania Food and Nutrition Centre, Dar es Salaam, Tanzania. ${ }^{9}$ Council for Scientific and Industrial Research Secretariat, Accra, Ghana. ${ }^{10}$ Direction des Études de la Recherche et de la Formation, Comité National d' Éthique, Dakar, Senegal. \\ ${ }^{11}$ National Institute of Public Health, Ministry of Health, Vientiane, Lao People's Democratic Republic.}

\section{Authors' contributions}

SJH, GEG, JNL, GDN, EJAO, MFS and BB contributed substantially to the study concept and design, the acquisition of data, or the analysis and interpretation of data, and revised the article critically for important intellectual content. SJH led the drafting of the paper, GEG led the data analysis, and JNL led the overall study design. All authors gave their approval for this paper to be published.

\section{Competing interests}

The authors declare that they have no competing interests.

Received: 19 August 2011 Accepted: 13 December 2011 Published: 13 December 2011

\section{References}

1. Haines A, Kuruvilla S, Borchert M: Bridging the implementation gap between knowledge and action for health. Bull World Health Organ 2004, 82:724-731.

2. World Health Organization: World report on knowledge for better health: Strengthening health systems Geneva: World Health Organization; 2004

3. Jones G, Steketee RW, Black RE, Bhutta ZA, Morris SS, Bellagio Child Survival Study Group: How many child deaths can we prevent this year? Lancet 2003, 362:65-71

4. Lengeler C: Insecticide-treated bed nets and curtains for preventing malaria. Cochrane Database Syst Rev 2004, CD000363.

5. Gamble C, Ekwaru JP, ter Kuile FO: Insecticide-treated nets for preventing malaria in pregnancy. Cochrane Database Syst Rev 2006, CD003755.

6. Gamble C, Ekwaru PJ, Garner P, ter Kuile FO: Insecticide-treated nets for the prevention of malaria in pregnancy: a systematic review of randomised controlled trials. PLoS Med 2007, 4:e107.

7. Roll Back Malaria Partnership: The Global Malaria Action Plan: For a MalariaFree World Geneva: Roll Back Malaria Partnership; 2008.

8. Teklehaimanot A, McCord GC, Sachs JD: Scaling up malaria control in Africa: an economic and epidemiological assessment. Am J Trop Med Hyg 2007, 77:138-144.

9. Snow RW, Guerra CA, Mutheu JJ, Hay SI: International funding for malaria control in relation to populations at risk of stable Plasmodium falciparum transmission. PLoS Med 2008, 7:e142.

10. Snow RW, Marsh K: Malaria in Africa: progress and prospects in the decade since the Abuja Declaration. Lancet 2010, 376:137-139.

11. World Health Organization: World Malaria Report 2009 Geneva: World Health Organization; 2009

12. World Health Assembly: WHA58.2: Malaria Control. Fifty-Eighth World Health Assembly World Health Organization. Geneva; 2005.

13. World Bank: The Millennium Development Goals for Health: Rising to the Challenges Washington DC: World Bank; 2004.

14. Bhattarai A, Ali AS, Kachur SP, Martensson A, Abbas AK, Khatib R, AlMafazy AW, Ramsan M, Rotllant G, Gerstenmaier JF, Molteni F, Abdulla S, Montgomery SM, Kaneko A, Bjorkman A: Impact of artemisinin-based combination therapy and insecticide-treated nets on malaria burden in Zanzibar. PLoS Med 2007, 4:e309.

15. United Nations: The Millennium Development Goals Report 2009 New York: United Nations; 2009.

16. Deressa W, Ali A, Enquoselassie F: Knowledge, attitude and practice about malaria the mosquito and antimalarial drugs in a rural community. Ethiopian J Health Dev 2003, 17:99-104.

17. Ahorlu CK, Dunyo SK, Afari EA, Koram KA, Nkrumah FK: Malaria-related beliefs and behaviour in southern Ghana: implications for treatment, prevention and control. Trop Med Int Health 1997, 2:488-499.

18. NetMark: NetMark 2004 survey on insecticide-treated nets (ITNS) in Ghana Washington DC: NetMark; 2005.

19. Nieto T, Mendez F, Carrasquilla G: Knowledge, beliefs and practices relevant for malaria control in an endemic urban area of the Colombian Pacific. Soc Sci Med 1999, 49:601-609.

20. Simsek Z, Kurcer MA: Malaria: knowledge and behaviour in an endemic rural area of Turkey. Public Health 2005, 119:202-208.

21. Pistone T, Guibert P, Gay F, Malvy D, Ezzedine K, Receveur MC, Siriwardana M, Larouze B, Bouchaud O: Malaria risk perception, knowledge and prophylaxis practices among travellers of African ethnicity living in Paris and visiting their country of origin in subSaharan Africa. Trans R Soc Trop Med Hyg 2007, 101:990-995.

22. Mwenesi $H$, Harpham T, Snow RW: Child malaria treatment practices among mothers in Kenya. Soc Sci Med 1995, 40:1271-1277. 
23. Espino F, Manderson L, Acuin C, Domingo F, Ventura E: Perceptions of malaria in a low endemic area in the Philippines: transmission and prevention of disease. Acta Trop 1997, 63:221-239.

24. Njama D, Dorsey G, Guwatudde D, Kigonya K, Greenhouse B, Musisi S, Kamya MR: Urban malaria: primary caregivers' knowledge, attitudes, practices and predictors of malaria incidence in a cohort of Ugandan children. Trop Med Int Health 2003, 8:685-692.

25. Kemble SK, Davis JC, Nalugwa T, Njama-Meya D, Hopkins H, Dorsey G, Staedke SG: Prevention and treatment strategies used for the community management of childhood fever in Kampala, Uganda. Am J Trop Med Hyg 2006, 74:999-1007.

26. Miguel CA, Tallo VL, Manderson L, Lansang MA: Local knowledge and treatment of malaria in Agusan del Sur, The Philippines. Soc Sci Med 1999, 48:607-618.

27. Cropley L: The effect of health education interventions on child malaria treatment-seeking practices among mothers in rural refugee villages in Belize, Central America. Health Promot Int 2004, 19:445-452.

28. Sanjana P, Barcus MJ, Bangs MJ, Ompusunggu S, Elyazar I, Marwoto H, Tuti S, Sururi M, Tjokrosonto S, Baird JK: Survey of community knowledge, attitudes, and practices during a malaria epidemic in central Java, Indonesia. Am J Trop Med Hyg 2006, 75:783-789.

29. Dulhunty JM, Yohannes K, Kourleoutov C, Manuopangai VT, Polyn MK, Parks WJ, Bryan JH: Malaria control in central Malaita, Solomon Islands 2. Local perceptions of the disease and practices for its treatment and prevention. Acta Trop 2000, 75:185-196.

30. Yohannes K, Dulhunty JM, Kourleoutov C, Manuopangai VT, Polyn MK, Parks WJ, Williams GM, Bryan JH: Malaria control in central Malaita, Solomon Islands. 1. The use of insecticide-impregnated bed nets. Acta Trop 2000, 75:173-183.

31. Kengeya-Kayondo JF, Seeley JA, Kajura-Bajenja E, Kabunga E, Mubiru E, Sembajja F, Mulder DW: Recognition, treatment seeking behaviour and perception of cause of malaria among rural women in Uganda. Acta Trop 1994, 58:267-273.

32. Schultz LJ, Ettling M, Chitsulo L, Steketee RW, Nyasulu Y, Macheso A, Nwanyanwu OC: A nation-wide malaria knowledge, attitudes and practices survey in Malawi: objectives and methodology. Trop Med Parasitol 1994, 45:54-56.

33. Adera TD: Beliefs and traditional treatment of malaria in Kishe settlement area, southwest Ethiopia. Ethiop Med J 2003, 41:25-34.

34. Keating J, Eisele TP, Bennett A, Johnson D, Macintyre K: A description of malaria-related knowledge, perceptions, and practices in the Artibonite Valley of Haiti: implications for malaria control. Am J Trop Med Hyg 2008, 78:262-269.

35. Oguonu T, Okafor H, Obu H: Caregivers' knowledge, attitude and practice on childhood malaria and treatment in urban and rural communities in Enugu, south-east Nigeria. Public Health 2005, 119:409-414.

36. Govere J, Durrheim D, La Grange K, Mabuza A, Booman M: Community knowledge and perceptions about malaria and practices influencing malaria control in Mpumalanga province, South Africa. S Afr Med J 2000, 90:611-616.

37. Hlongwana K, Mabaso M, Kunene S, Govender D, Maharaj R: Community knowledge, attitudes and practices (KAP) on malaria in Swaziland: A country earmarked for malaria elimination. Malar J 2009, 8:29.

38. Paulander J, Olsson H, Lemma H, Getachew A, San Sebastian M: Knowledge, attitudes and practice about malaria in rural Tigray, Ethiopia. Global Health Action 2009, 2.

39. Gingrich CD, Hanson KG, Marchant TJ, Mulligan J-A, Mponda H: Household demand for insecticide-treated bednets in Tanzania and policy options for increasing uptake. Health Policy Plan 2011, 26:133-141.

40. Stead LF, Bergson G, Lancaster T: Physician advice for smoking cessation. Cochrane Database Syst Rev 2008, CD000165.

41. Rice VH, Stead LF: Nursing interventions for smoking cessation. Cochrane Database Syst Rev 2008, CD001188.

42. Sinclair HK, Bond CM, Stead LF: Community pharmacy personnel interventions for smoking cessation. Cochrane Database Syst Rev 2004, CD003698

43. Brunner EJ, Rees K, Ward K, Burke M, Thorogood M: Dietary advice for reducing cardiovascular risk. Cochrane Database Syst Rev 2007, CD002128.

44. Hooper L, Bartlett C, Davey SG, Ebrahim S: Advice to reduce dietary salt for prevention of cardiovascular disease. Cochrane Database Syst Rev 2004, CD003656.
45. Onwujekwe O, Uzochukwu B, Dike N, Uguru N, Nwobi E, Shu E: Malaria treatment perceptions, practices and influences on provider behaviour: comparing hospitals and non-hospitals in south-east Nigeria. Malar J 2009, 8:246.

46. Smith LA, Jones $C$, Meek S, Webster J: Provider practice and user behavior interventions to improve prompt and effective treatment of malaria: do we know what works? Am J Trop Med Hyg 2009, 80:326-335.

47. Mayxay M, Pongvongsa T, Phompida S, Phetsouvanh R, White NJ, Newton PN: Diagnosis and management of malaria by rural community health providers in the Lao People's Democratic Republic (Laos). Trop Med Int Health 2007, 12:540-546.

48. Wagbatsoma VA, Ogbeide O: Towards malaria control: the knowledge of health care providers about mosquito and malaria transmission. Cent Afr J Med 1999, 45:4-6.

49. Nahum A, Akogbeto M: [Malaria and pregnancy: attitude of health care personnel during prenatal care in Cotonou, Benin]. Med Trop (Mars) 2000, 60:251-255.

50. Faye O, Ndir O, Gaye O, Bah IB, Dieng T, Dieng Y, Diallo S, Diagne AK: [Health personnel and population practices in the diagnosis of malaria and use of antimalarial drugs in Dakar]. Med Trop (Mars) 1995, 55:47-50.

51. Studts $\lrcorner L$, Burris $J$, Kearns DK, Worth $C T$, Sorrell $C L$ : "Providers practice prevention": promoting dental hygienists' use of evidence-based treatment of tobacco use and dependence. J Dent Educ 2009, 73:1069-1082.

52. Sheffer $C E$, Barone $C P$, Anders ME: Training health care providers in the treatment of tobacco use and dependence: pre- and post-training results. J Eval Clin Pract 2009, 15:607-613.

53. Applegate BW, Sheffer CE, Crews KM, Payne TJ, Smith PO: A survey of tobacco-related knowledge, attitudes and behaviours of primary care providers in Mississippi. J Eval Clin Pract 2008, 14:537-544.

54. Bigelow C, Patton LL, Strauss RP, Wilder RS: North Carolina dental hygienists' view on oral cancer control. J Dent Hyg 2007, 81:83.

55. Jenkins K, Ahijevych K: Nursing students' beliefs about smoking, their own smoking behaviors, and use of professional tobacco treatment intervention. Appl Nurs Res 2003, 16:164-172.

56. Menees SB, Patel DA, Dalton V: Colorectal cancer screening practices among obstetrician/gynecologists and nurse practitioners. J Women's Health (Larchmont) 2009, 18:1233-1238.

57. Rim SH, Zittleman L, Westfall JM, Overholser L, Froshaug D, Coughlin SS: Knowledge, attitudes, beliefs, and personal practices regarding colorectal cancer screening among health care professionals in rural Colorado: a pilot survey. J Rural Health 2009, 25:303-308.

58. Berkowitz Z, Hawkins NA, Peipins LA, White MC, Nadel MR: Beliefs, risk perceptions, and gaps in knowledge as barriers to colorectal cancer screening in older adults. J Am Geriatr Soc 2008, 56:307-314.

59. Sabatino SA, McCarthy EP, Phillips RS, Burns RB: Breast cancer risk assessment and management in primary care: provider attitudes, practices, and barriers. Cancer Detect Pre J 2007, 31:375-383.

60. Daley MF, Liddon N, Crane LA, Beaty BL, Barrow J, Babbel C, Markowitz LE, Dunne EF, Stokley S, Dickinson LM, Berman S, Kempe A: A national survey of pediatrician knowledge and attitudes regarding human papillomavirus vaccination. Pediatrics 2006, 118:2280-2289.

61. Nizami SQ, Khan IA, Bhutta ZA: Differences in self-reported and observed prescribing practice of general practitioners and paediatricians for acute watery diarrhoea in children of Karachi, Pakistan. J Diarrhoeal Dis Res 1995, 13:29-32.

62. Kundi MZ, Ahmad I, Anjum M: Evaluation of diarrhoea management of health professionals trained at the Diarrhoea Training Unit of Rawalpindi General Hospital. J Pak Med Assoc 1997, 47:3-6.

63. Ibrahim S, Isani Z: Evaluation of doctors trained at Diarrhoea Training Unit of National Institute of Child Health, Karachi. J Pak Med Assoc 1997 47:7-11.

64. Kasi M, Kausar P, Naz R, Miller LC: Treatment of diarrhoea in infants by medical doctors in Balochistan, Pakistan. J Diarrhoeal Dis Res 1995, 13:238-241.

65. Singh J, Bora D, Sachdeva V, Sharma RS, Verghese T: Prescribing pattern by doctors for acute diarrhoea in children in Delhi, India. J Diarrhoeal Dis Res 1995, 13:229-231.

66. Raghu MB, Balasubramanian S, Indumathy, Balasubrahmanyam G: Awareness of and attitude towards oral rehydration therapy. Indian $J$ Pediatr 1995, 62:439-443. 
67. Ozuah PO, Avner JR, Stein RE: Oral rehydration, emergency physicians, and practice parameters: a national survey. Pediatrics 2002, 109:259-261.

68. Choudhry AJ, Mubasher M: Factors influencing the prescribing patterns in acute watery diarrhoea. J Pak Med Assoc 1997, 47:32-35.

69. Steiner MJ, Raymond E, Attafuah JD, Hays M: Provider knowledge about emergency contraception in Ghana. J Biosoc Sci 2000, 32:99-106.

70. Suhaimi $\mathrm{H}$, Monga D, Siva A: A study of knowledge and attitudes towards contraception among health care staff in Kelantan (Malaysia). Singapore Med J 1996, 37:51-54.

71. Khasiani SA: Family planning knowledge, attitudes and practices among health centre personnel in Western Province of Kenya. J Obstet Gynaecol East Cent Afr 1991, 9:30-36.

72. Quereshi ZP, Sekadde-kigondu CB: A survey to determine the knowledge, attitudes and practice of family planning amongst the nursing staff at Kenyatta National Hospital. J Obstet Gynaecol East Cent Afr 1991, 9:49-51.

73. Gaffikin L, Phiri A, McGrath J, Zinanga A, Blumenthal PD: Provider attitudes toward IUD provision in Zimbabwe: perception of HIV risk and training implications. Adv Contracept 1998, 14:27-39.

74. Guindon GE, Lavis J, Boupha B, Shi G, Sidibe M, Turdaliyeva B, Research to Policy and Practice Study Team: Bridging the gaps among research, policy and practice in ten low- and middle-income countries: Development and testing of a questionnaire for health-care providers. Health Res Policy Syst 2010, 8:3.

75. Guindon GE, Lavis JN, Becerra-Posada F, Malek-Afzali H, Shi G, Yesudian CAK, Hoffman SJ, for the Research to Policy and Practice Study Team: Bridging the gaps between research, policy and practice in lowand middle-income countries: a survey of health care providers. Can Med Assoc J 2010, 182:E362-372.

76. Cameron D, Lavis JN, Guindon GE, Akhtar T, Becerra Posada F, Ndossi G, Boupha B, Research to Policy and Practice Study Team: Bridging the gaps among research, policy and practice in ten low- and middle-income countries: Development and testing of a questionnaire for researchers. Health Res Policy Syst 2010, 8:4.

77. Lavis JN, Guindon GE, Cameron D, Boupha B, Dejman M, Osei EJA, Sadana R, for the Research to Policy and Practice Study Team: Bridging the gaps between research, policy and practice in low- and middle-income countries: a survey of researchers. Can Med Assoc J 2010, 182:E350-361.

78. McColl A, Smith H, White P, Field J: General practitioner's perceptions of the route to evidence based medicine: a questionnaire survey. BMJ 1998, 316:361-365

79. Incorporated MI: Demographic and Health Surveys: The Service Provision Assessment Calverton, Maryland: Macro International Incorporated; 2004

80. Page J, Heller RF, Kinlay S, Lim LL, Qian W, Suping Z, Kongpatanakul S, Akhtar M, Khedr S, Macharia W: Attitudes of developing world physicians to where medical research is performed and reported. BMC Public Health 2003, 3:6.

81. Prescott K, Lloyd M, Douglas HR, Haines A, Humphrey C, Rosenthal J, Watt I: Promoting clinically effective practice: general practitioners' awareness of sources of research evidence. Fam Pract 1997, 14:320-323.

82. Wilson P, Droogan J, Glanville J, Watt I, Hardman G: Access to the evidence base from general practice: a survey of general practice staff in Northern and Yorkshire Region. Qual Saf Health Care 2001, 10:83-89.

83. Wilson P, Glanville J, Watt I: Access to the online evidence base in general practice: a survey of the Northern and Yorkshire Region. Health Inf Libr J 2003, 20:172-178.

84. World Health Organization: WHO Health Research Utilization Assessment Project: Questionnaire for Health Providers -Pilot Principal investigator: Shyama Kuruvilla. Geneva: World Health Organization; 2002.

85. World Health Organization: Integrated Management of Childhood IIIness (IMCI) Multi-Country Evaluation - Health Facility Survey Geneva: World Health Organization; 2004

86. Landry R, Lamari M, Amara N: The extent and determinants of the utilization of university research in government agencies. Public Adm Rev 2003, 63:192-205.

87. Net Gain: Operational Aspects of a New Health Intervention for Preventing Malaria Death. Edited by: Lengeler C, Cattani J, Savigny D. Geneva and Ottawa: World Health Organization and International Development Research Centre; 1997:.

88. Lines JD, Myamba J, Curtis CF: Experimental hut trials of permethrinimpregnated mosquito nets and eave curtains against malaria vectors in Tanzania. Med Vet Entomol 1987, 1:37-51.
89. Maxwell CA, Chambo W, Mwaimu M, Magogo F, Carneiro IA, Curtis CF: Variation of malaria transmission and morbidity with altitude in Tanzania and with introduction of alphacypermethrin treated nets. Malar J 2003, 2:28

90. Tami A, Mubyazi G, Talbert A, Mshinda H, Duchon S, Lengeler C: Evaluation of Olyset insecticide-treated nets distributed seven years previously in Tanzania. Malar J 2004, 3:19.

91. United Nations Population Division: World Population Prospects: The 2004 Revision New York: United Nations; 2005.

92. International Monetary Fund: World Economic Outlook Database. Washington DC: International Monetary Fund; 2007.

93. World Health Organization: World Health Statistics 2007 Geneva: World Health Organization; 2007.

94. United Nations Statistics Division: United Nations Common Database New York: United Nations; 2008

95. United Nations Children's Fund: The State of the World's Children $2008 \mathrm{New}$ York: United Nations; 2007.

96. StataCorp: Stata Multiple Imputation Reference Manual Release 11 College Station, Texas: Stata Press; 2009

97. Cook DJ, Mulrow CD, Haynes RB: Systematic reviews: synthesis of best evidence for clinical decisions. Ann Intern Med 1997, 126:376-380.

98. Lavis JN, Davies HT, Gruen RL, Walshe K, Farquhar CM: Working within and beyond the cochrane collaboration to make systematic reviews more useful to healthcare managers and policy makers. Healthcare Policy 2006, 1:21-33.

99. Oxman AD, Guyatt G: When to Believe a Subgroup Analysis. In Users Guide to the Medical Literature: A Manual for Evidence-Based Clinical Practice. Edited by: Guyatt G. Chicago: AMA Press; 2002:553-565.

100. Haynes RB, Mulrow CD, Huth EJ, Altman DG, Gardner MJ: More informative abstracts revisited. Ann Intern Med 1990, 113:69-76.

101. Better Doctors, Better Patients, Better Decisions: Envisioning Health Care 2020. Edited by: Gigerenzer G, Gray JAM. Cambridge, MA: MIT Press; 2011:

102. Zonfrillo MR, Nelson KA, Durbin DR: Emergency physicians' knowledge and provision of child passenger safety information. Acad Emerg Med 2011, 18:145-151

103. Shih YC, Sleath BL: Health care provider knowledge of drug formulary status in ambulatory care settings. Am J Health Syst Pharm 2004, 61:2657-2663.

104. Hodges B, Inch C, Silver I: Improving the psychiatric knowledge, skills, and attitudes of primary care physicians, 1950-2000: a review. Am J Psychiatry 2001, 158:1579-1586.

105. Parada JP, Schwartz DN, Schiff GD, Weiss KB: Effects of type and level of training on variation in physician knowledge in the use and acquisition of blood cultures: a cross sectional survey. BMC Infect Dis 2005, 5:71.

106. Soons KR, Lynch $T$, Seagrave $M$, Rolley L: Determining physicians' knowledge and attitudes when prescribing drugs to treat gastrointestinal disorders. Clin Perform Qual Health Care 1997, 5:94-98.

107. Mona Eng P, Seeger JD, Loughlin J, Oh K, Walker AM: Serum potassium monitoring for users of ethinyl estradiol/drospirenone taking medications predisposing to hyperkalemia: physician compliance and survey of knowledge and attitudes. Contraception 2007, 75:101-107.

108. Volpe M, Dedhiya SD: Physicians, patients, and public knowledge and perception regarding hypertension and stroke: a review of survey studies. Curr Med Res Opin 2006, 22:1319-1330.

109. Zickmund SL, Brown KE, Bielefeldt K: A systematic review of provider knowledge of hepatitis C: is it enough for a complex disease? Dig Dis Sci 2007, 52:2550-2556.

110. Zeteroglu S, Sahin G, Sahin HA, Bolluk G: Knowledge and attitudes towards emergency contraception of health-care providers in a region with a high birth rate. Eur J Contracept Reprod Health Care 2004, 9:102-106.

111. Krille L, Hammer GP, Merzenich H, Zeeb H: Systematic review on physician's knowledge about radiation doses and radiation risks of computed tomography. Eur J Radiol 2010, 76:36-41.

112. Wurst KE, Sleath BL: Physician knowledge and adherence to prescribing antibiotic prophylaxis for sickle cell disease. Int J Qual Health Care 2004, 16:245-251.

113. Kimura S, Pacala JT: Pressure ulcers in adults: family physicians' knowledge, attitudes, practice preferences, and awareness of AHCPR guidelines. J Fam Pract 1997, 44:361-368.

114. Chin MH, Friedmann PD, Cassel CK, Lang RM: Differences in generalist and specialist physicians' knowledge and use of angiotensin-converting 
enzyme inhibitors for congestive heart failure. J Gen Intern Med 1997, 12:523-530.

115. Linnehan MJ, Andrews S, Groce NE: College health providers' knowledge, attitudes, and management practices of genital HPV infection. Nurse Pract 1996, 21:122-124, 127-129.

116. van Gerwen M, Franc C, Rosman S, Le Vaillant M, Pelletier-Fleury N: Primary care physicians' knowledge, attitudes, beliefs and practices regarding childhood obesity: a systematic review. Obesity Rev 2009, 10:227-236.

117. Wolfert MZ, Gilson AM, Dahl JL, Cleary JF: Opioid analgesics for pain control: wisconsin physicians' knowledge, beliefs, attitudes, and prescribing practices. Pain Med 2010, 11:425-434.

118. Socolar RR, Raines B, Chen-Mok M, Runyan DK, Green C, Paterno S: Intervention to improve physician documentation and knowledge of child sexual abuse: a randomized, controlled trial. Pediatrics 1998, 101:817-824.

119. Chen DT, Wynia MK, Moloney RM, Alexander GC: U.S. physician knowledge of the FDA-approved indications and evidence base for commonly prescribed drugs: results of a national survey. Pharmacoepidemiol Drug Saf 2009, 18:1094-1100

120. Carr VJ, Faehrmann C, Lewin TJ, Walton JM, Reid AA: Determining the effect that consultation-liaison psychiatry in primary care has on family physicians' psychiatric knowledge and practice. Psychosomatics 1997, 38:217-229.

121. Barker GJ, Epstein JB, Williams KB, Gorsky M, Raber-Durlacher JE: Current practice and knowledge of oral care for cancer patients: a survey of supportive health care providers. Support Care Cancer 2005, 13:32-41.

122. Zierler BK, Meissner MH, Cain K, Strandness DE Jr: A survey of physicians' knowledge and management of venous thromboembolism. Vasc Endovasc Surgery 2002, 36:367-375.

123. Grimshaw JM, Shirran L, Thomas R, Mowatt GF, Bero L, Grilli R, Harvey E, Oxman A, O'Brien MA: Changing provider behavior: an overview of systematic reviews of interventions. Med Care 2001, 39:112-145.

124. Grimshaw JM, Thomas RE, MacLennan G, Fraser C, Ramsay CR, Vale L, Whitty P, Eccles MP, Matowe L, Shirran L, Wensing M, Dijkstra R, Donaldson C: Effectiveness and efficiency of guideline dissemination and implementation strategies. Health Technol Assess 2004, 8:iii-iv, 1-72.

125. Jamtvedt G, Young JM, Kristoffersen DT, O'Brien MA, Oxman AD: Audit and feedback: effects on professional practice and health care outcomes. Cochrane Database Syst Rev 2006, 2:CD000259.

126. Farmer AP, Légaré F, Turcot L, Grimshaw J, Harvey E, McGowan JL, Wolf F: Printed educational materials: effects on professional practice and health care outcomes. Cochrane Database Syst Rev 2008, 3:CD004398.

127. Forsetlund L, Bjørndal A, Rashidian A, Jamtvedt G, O'Brien MA, Wolf F, Davis D, Odgaard-Jensen J, Oxman AD: Continuing education meetings and workshops: effects on professional practice and health care outcomes. Cochrane Database Syst Rev 2009, 2:CD003030.

128. Flodgren G, Parmelli E, Doumit G, Gattellari M, O'Brien MA, Grimshaw J, Eccles MP: Local opinion leaders: effects on professional practice and health care outcomes. Cochrane Database Syst Rev 2007, 1:CD000125.

129. Shojania KG, Jennings A, Mayhew A, Ramsay CR, Eccles MP, Grimshaw J: The effects of on-screen, point of care computer reminders on processes and outcomes of care. Cochrane Database Syst Rev 2009, 3: CD001096.

130. Rx for Change. [http://www.rxforchange.com]

131. Health Systems Evidence. [http://www.healthsystemsevidence.org].

132. Adams AS, Soumerai SB, Lomas J, Ross-Degnan D: Evidence of self-report bias in assessing adherence to guidelines. Int I Qual Health Care 1999, 11:187-192.

doi:10.1186/1475-2875-10-363

Cite this article as: Hoffman et al:: Assessing healthcare providers' knowledge and practices relating to insecticide-treated nets and the prevention of malaria in Ghana, Laos, Senegal and Tanzania. Malaria Journal 2011 10:363.

\section{Submit your next manuscript to BioMed Central and take full advantage of:}

- Convenient online submission

- Thorough peer review

- No space constraints or color figure charges

- Immediate publication on acceptance

- Inclusion in PubMed, CAS, Scopus and Google Scholar

- Research which is freely available for redistribution

Submit your manuscript at www.biomedcentral.com/submit 